\section{Penn State High Tunnel Extension Program}

\author{
William J. Lamont, Jr., ${ }^{1}$ Michael D. Orzolek, ${ }^{2}$ \\ E. Jay Holcomb, ${ }^{3}$ Robert M. Crassweller, ${ }^{4}$ \\ Kathy Demchak, ${ }^{5}$ Eric Burkhart, ${ }^{6}$ Lisa White, ${ }^{7}$ \\ and Bruce Dye ${ }^{8}$
}

Additional indeX wORDs. education, outreach

Summary. The Center for Plasticulture's High Tunnel Research and Education Facility was established at Pennsylvania State University in 1999. Since its inception, applied research has been conducted at this facility by a team of researchers and extension specialists on the development of a new high tunnel design. The development of crop production recommendations for vegetables, small fruits, tree fruits and cut flowers grown in high tunnels has been a priority. To complement the applied research program, an aggressive extension education program was developed to extend information on the technology of high tunnels to county extension personnel, growers, industry representatives, students, master gardeners and the general public. The extension programming effort consisting of demonstration high tunnels, field days, tours, in-service training, publications and presentations made at winter meetings will be discussed in the report below.

S ince 1999 a team of researchers and extension specialists at the Penn State High Tunnel Research and Education Facility (HTREF) has conducted applied research on vegetables, small fruits, cut flowers, and tree fruits related to crop and pest management in high tunnels. High tunnels are an affordable season extension technology for producing a wide variety of horticultural crops. They are generally quonset-shape, constructed of metal bows attached to metal posts that have been driven into the ground. They are covered with a single layer of 6-mil [0.006inch $(0.1524-\mathrm{mm})]$ greenhouse grade polyethylene and are ventilated by manually rolling up the sides. There is no permanent heating system although it is advisable to have a standby portable propane unit to protect against unexpected below-freezing temperatures. There are no electrical connections. The only external connection is a water supply for drip/ trickle irrigation. For more detailed information on the construction of a high tunnel see Lamont et al., 2002. To

\footnotetext{
Department of Horticulture, Pennsylvania State University, University Park, PA 16802 .

${ }^{1}$ Associate professor of vegetable crops.

${ }^{2}$ Professor of vegetable crops.

${ }^{3}$ Professor of floriculture

${ }^{4}$ Professor of tree fruit.

${ }^{5}$ Senior extension associate.

${ }^{6}$ Graduate research assistant.

${ }^{7}$ Manager of the High Tunnel Research and Education Facility.

${ }^{8}$ Research support associate.
}

disseminate this information to county extension personnel, growers, industry representatives, students, master gardeners, and the general public a wide variety of extension educational programming methods are being used.

The best way to teach growers how to use a high tunnel is to show them the system in action. To this end, we developed demonstration high tunnels throughout the state, trained county extension personnel, provided tours for Master Gardeners and incorporated tours of these facilities into a variety of field days and agricultural events.

\section{Demonstration high tunnels out in the state}

In addition to the HTREF at Rock Springs, Pa., 12 demonstration high tunnels have been constructed throughout the state. These high tunnel projects are a cooperative effort between county extension personnel, and growers or vocational agricultural teachers. The high tunnels are $17 \mathrm{ft}$ wide $\times 36 \mathrm{ft}$ long $(5.2 \times 11.0 \mathrm{~m})$ and are located with growers in Blair, Bucks, Elk, Erie, Indiana, Lackawanna, Lancaster, and Potter counties. Three additional high tunnels are located at high schools in Dauphin (Milton S. Hershey School, Hershey, Pa.), Philadelphia (W.B. Saul High School, Philadelphia, Pa.), and Potter (North Potter High School, Ulysses, Pa.) counties (Fig. 1). In addition, one high tunnel $17 \mathrm{ft}$ wide $\times 48 \mathrm{ft}$ long $(5.2 \times 14.6 \mathrm{~m})$ is located at the county extension office in Franklin County. The crop selection decision is determined by the extension agent and cooperating grower or vocational agricultural teacher. Production and pest management information collected at these sites is placed on the Center for Plasticulture web site at <http:// plasticulture.cas.psu.edu> (Wodecki et al., 2001) and also disseminated via the Vegetable and Small Fruit Gazette, a monthly extension newsletter, or at county extension field days and winter meetings. The satellite high tunnels were cooperatively financed by the HTREF and local county extension office.

\section{In-service training programs}

Four in-service training programs for county extension personnel have been held at the HTREF. The in-service programs were designed to demonstrate the construction, management and production techniques for high tunnels so extension agents could assist growers who purchase high tunnels in Pennsylvania. The programs offered and number of participating extension agents are as follows: 1998, Construction of High Tunnels Part I, Rock Springs, Pa., 13 participants; 1999, Construction of High Tunnels Part II, Rock Springs, Pa., 15 participants; 2000, Operation of High Tunnels, Rock Springs, Pa., 27 participants; and 2001, Update on Production in High Tunnels, Rock Springs, Pa., 35 participants.

A paper on economics of high tunnel production "High Tunnels: How Can They Make Me Money" (J.K. Harper, unpublished), a production manual "The Penn State High Tunnel Research and Education Facility “(W.J. Lamont et al., unpublished), and a brochure "Center for Plasticulture" (W.J. Lamont and M.D. Orzolek, unpublished) were prepared for the most recent in-service training program. (Fig. 2).

\section{Ag Progress Days}

Ag Progress Days is a very large 3-d agricultural field exhibition held each year at the Russell E. Larson Agricultural Research Center, Rock Springs, Pa. Attendance includes growers, government officials, gardeners and 

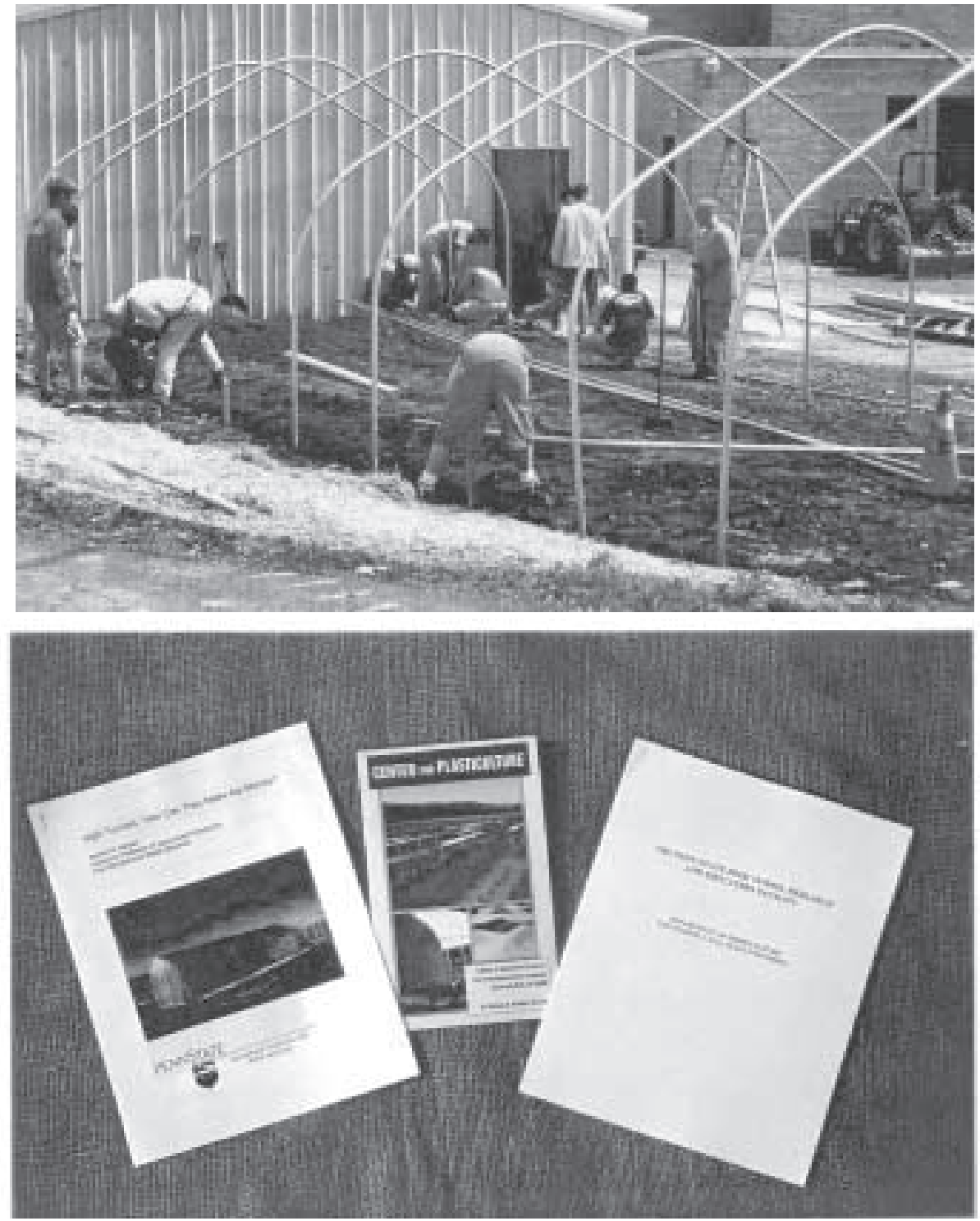

Fig. 2. Resource materials developed by Penn State University extension specialists/researchers for the 2001 "Update on Production in High Tunnels" in-service training program conducted for county extension personnel.

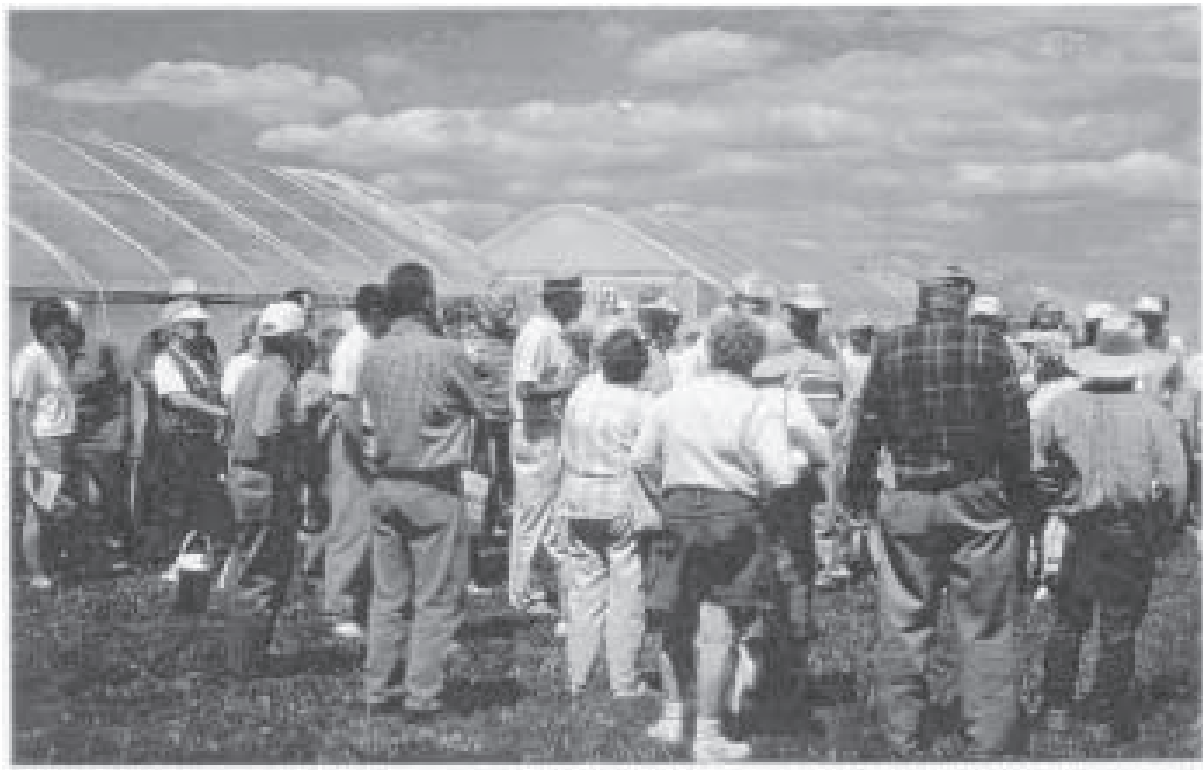

Fig. 1. Vocational agricultural students at North Potter High School, Ulysses, Pa., assisting Penn State extension specialists and county extension personnel in the construction of a $17 \times 36-\mathrm{ft}(5.2 \times 11.0-\mathrm{m})$ high tunnel located at the high school.

homeowners wishing to learn new technology developed each year in all phases of agriculture. In both 2000 and 2001, tours of the HTREF were conducted on each day of the 3-d event (Fig. 3). A total of 585 people toured the facility and learned more about high tunnel construction and production.

\section{Vegetable and Small Fruit Field Day}

The Vegetable and Small Fruit field day is an alternate year event held on even years at the Horticulture Research Farm. It is jointly sponsored by Penn State University and the Pennsylvania Vegetable Growers Association. A total of 180 growers toured horticultural field research including the HTREF in 2000 .

\section{Master Gardener in-service}

As part of the annual Master Gardener's in-service training conducted at Penn State, tours of the high tunnels were conducted in 2000 and 2001 educating over 100 Master Gardeners on crop production and pest management in high tunnels.

\section{Pennsylvania's Governor's School}

The Pennsylvania's Governor's School is a program held each summer at Penn State University to provide 1) educational programs in agriculture and environmental science to gifted and talented high school age youth, 2) challenge these youth to use their talent and intellect in studying and researching the scientific nature of agriculture, and its interrelationship with the environment, and 3) acquaint high school age youth with the scientific and professional opportunities available to them in the food, agriculture, and natural resource sciences. Students participat-

Fig. 3. Tour being conducted of the Penn State High Tunnel Research and Education Facility during Ag Progress Days, the very large 3-d agricultural field exhibition held each year at the Russell E. Larson Agricultural Research Center, Rock Springs, Pa. 

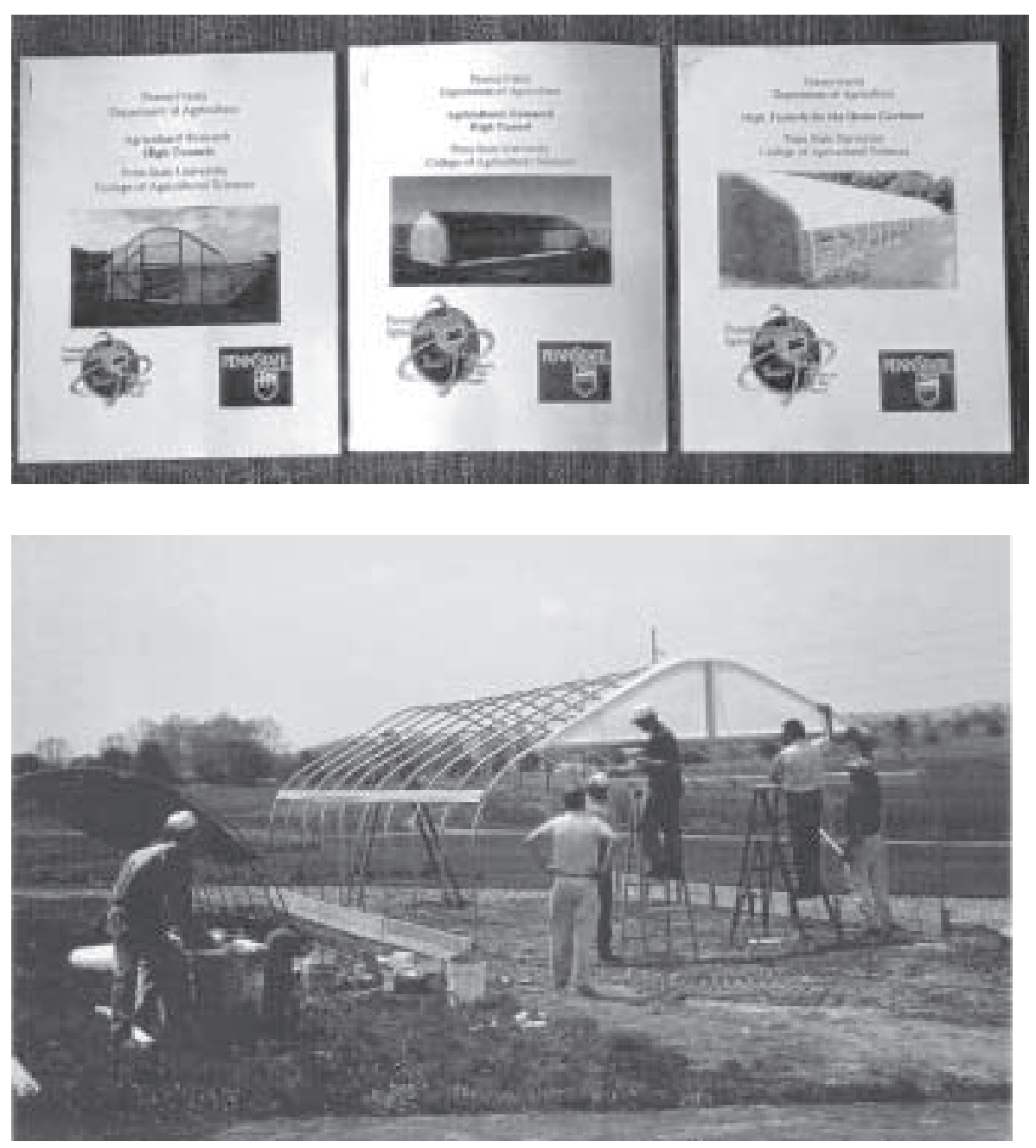

Fig. 5. Erection of a high tunnel using the Penn State design at the Milton Hershey School, Hershey, Pa., provided an opportunity for hands-on training for county extension agents from southeastern Pennsylvania.

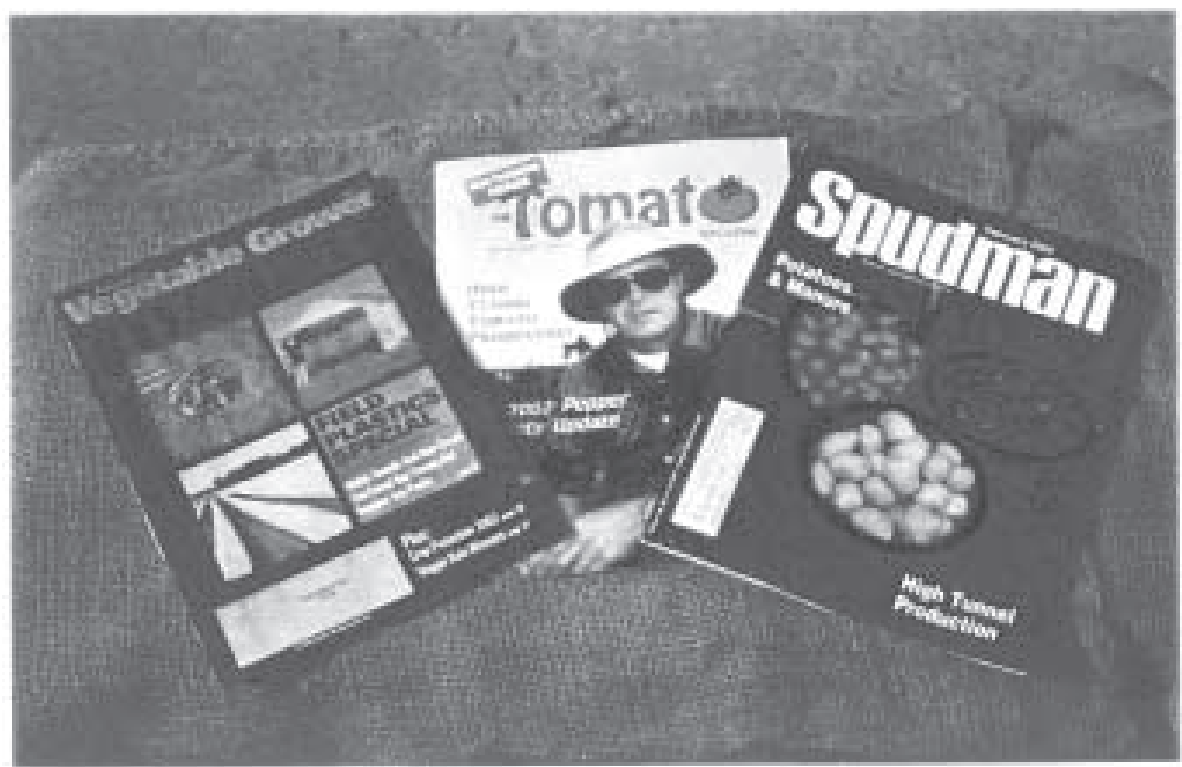

Fig. 6. Examples of trade magazines in which researchers and extension specialists associated with the Penn State High Tunnel Research and Education Facility have written articles on production of horticultural crops in high tunnels.
Fig. 4. Handouts developed by Pennsylvania Department of Ägriculture and Penn State University personnel for dissemination at the display showcasing the Penn State High Tunnel Research and Education Facility during the 2000 and 2001 Pennsylvania Farm Show, the large 6d exposition held at the Farm Show Arena in Harrisburg, Pa.

ing in the "Pennsylvania Governor's School for the Agricultural Sciences" toured the high tunnel facility in 2000 and 2001. A total of 79 high school students participated in the tours and learned about production and management of horticultural crops in high tunnels.

\section{Pennsylvania Farm Show}

The Pennsylvania Farm Show is a large 6-d exposition held at the Farm Show Arena in Harrisburg, Pa., and is one of the oldest agricultural exhibitions in the United States. The objective of the farm show is to present the newest technology in both plant and animal production to visitors of the exhibition. Attendance at the farm show includes growers, consumers, youth groups, government officials, industry representatives, extension personnel and representatives of the media (newspaper, trade publications, radio and television).

The Secretary of Agriculture, the Honorable Sam Hayes, showcased the Penn State high tunnel program at both the 2000 and 2001 Pennsylvania Farm Show. A $17 \times 36-\mathrm{ft}$ high tunnel was erected in the exposition hall and planted with a variety of horticultural crops. Extension specialists, researchers and technicians from the Penn State HTREF, as well as county extension agents and Master Gardeners were on hand to answer questions about high tunnels. In cooperation with the Pennsylvania Department of Agriculture, three handouts were developed for dissemination at the Farm Show event (Fig. 4). A total of 25,000 individuals visited the display. Members of the high tunnel research/ extension team and county extension personnel provided many interviews to radio stations and television stations and newspaper reporters.

\section{Pennsylvania Association for Sustainable Agriculture Field Day (PASA)}

PASA and Penn State jointly hosted a field day at the high tunnel facility. 
Fifty-six individuals toured the high tunnels and learned more about construction, operation, and production of crops in high tunnels. A 50-page high tunnel manual (W.J. Lamont et al., unpublished) was prepared for the participants.

\section{Guided tours of the HTREF}

Tours have been conducted for 35 extension specialists/ extension agents, researchers, industry representatives, growers or individuals from Arizona, California, Massachusetts, New York, New Jersey, Ohio, Virginia, North Carolina, Maryland, Indiana, Georgia, and New Hampshire. Tours have been conducted for 15 visitors from Canada, Australia, Egypt, Hungary, and India. Tours have been conducted for 28 growers from Pennsylvania interested in learning more about the high tunnels.

\section{Educational meetings}

Not everyone is able to attend a tour, so we also presented information about high tunnels at educational meetings throughout the state.

County extension meetings. At 16 county extension winter meetings held throughout the state presentations on various aspects of high tunnels were made through early 2002 , reaching a total of 1,165 growers.

Mid-Atlantic fruit and vegetable convention. This is a large annual commodity meeting held at the Hershey Lodge and Convention Center, Hershey, Pa. It is jointly sponsored by Penn State Cooperative Extension Service, Pennsylvania Vegetable Growers Association, State Horticultural Association of Pennsylvania, Maryland State Horticultural Society, and New Jersey State Horticulture Society. Presentations on high tunnels at this annual in-state convention reached more than 1,250 growers from 2000 to 2002.

Annual meeting of Pennsylvania Association for Sustainable Agriculture. The Pennsylvania Association for Sustainable Agriculture is a large and active organization representing growers from not only Pennsylvania, but also the northeast and mid-Atlantic region. Presentations on the Penn State high tunnel program was made at their annual meeting in 2001 and 2002 and reached more that 225 growers.

OUt-OF-STATE COMmodity meetings. Presentations were made on high tunnels at nine out-of-state commodity meetings in Ohio, New Jersey, New York, Delaware, West Virginia, Wisconsin, Missouri, Maryland, and Michigan from 1999 through 2002 reached 1,250 people.

American Society for Plasticulture congresses. Presentations on high tunnels at the $29^{\text {th }}$ and $30^{\text {th }}$ Agricultural Plastics Congress reached more that 350 persons. At the $29^{\text {th }}$ Congress which also was the $15^{\text {th }}$ International Congress, a 17 $\times 36$ - $\mathrm{ft}$ high tunnel was erected at the Milton Hershey School (Hershey, Pa.) and was part of a large field demonstration of the latest plasticulture technology. The erection of this high tunnel also served as hands-on training for county extension agents in the southeastern region (Fig. 5 ).

To extend high tunnel information, throughout the country and the world we developed a web site, produced a television segment and wrote articles for a variety of trade publications.

\section{Center for Plasticulture Web site}

A web site was developed for the dissemination of information pertaining to all phases of the use of plastics in the production of horticultural crops as well as the disposal of the used agricultural plastics. The web site address is <http:// plasticulture.cas.psu.edu> (Wodecki et al., 2001.

\section{Television}

An 8-min segment on high tunnel production filmed on location at the Penn State HTREF was aired on 24 Apr. 2002 on "The Martha Stewart Living Show." From that airing, over 50 requests for the "Penn State High Tunnel Construction Manual" (W.J. Lamont et al., unpublished) have been received from all over the United States, especially from the western U.S. Many individuals requesting the construction manual were homeowners that wanted to extend their growing season under their local weather conditions.

\section{Trade or popular press}

Members of the team have prepared articles on different aspects of high tunnels in a variety of trade publications that have reached a national and international readership (Lamont, 2002, Gordon, 2002, Lamont et al., 2001) (Fig. 6).

\section{Summary}

At Penn State we have used a wide variety of extension educational techniques to disseminate information on high tunnel technology. Different educational techniques allow us to reach as wide an audience as possible. The overall extension programming effort associated with the HTREF was able to introduce high tunnels and provide extension information on the design, construction, operation, environmental conditions in the high tunnels, crop production and economics to over 29,858 people since 1999. Estimates based on data obtained from county extension personnel, manufacturers of high tunnel kits and grower contacts indicate that over 350 new high tunnels have been constructed in Pennsylvania and the surrounding states since 1999. Dennis Peters, a young vegetable grower from York County Pennsylvania summed up the impact of our extension program. After touring the facility and attending presentations on high tunnel technology at the Mid-Atlantic Fruit and Vegetable Convention, he constructed a $17 \times 96$-ft $(5.2 \times 2.39 \mathrm{~m})$ high tunnel using the Penn State design and planted a tomato (Lycopersicon esculentum) crop. Dennis made the following statement: "Everything that I learned from Penn State about high tunnels was right on target and with the information and assistance I received, I was able to produce high quality tomatoes until December and I paid for the high tunnel the first year." This is the kind of impact the Penn State High Tunnel Extension Program is having throughout Pennsylvania and the mid-Atlantic region.

\section{Literature cited}

Gordon, R. 2002. The lowdown on high tunnels. Amer. Veg. Grower 50(2):14, 18-19.

Lamont, W.J., M.R. McGann, M.D. Orzolek, N. Mbugua, B. Dye, and D. Reese. Design and construction of the Penn State High Tunnel. 2002. HortTechnology 12(3):171-177.

Lamont, W.J., M.D. Orzolek, and J. Harper. 2001. A look at Penn State high tunnels for extending the tomato season. Tomato Mag. $5(6): 4-6,8-10$.

Lamont, W.J. 2002. High tunnel potatoes. Spudman 40(2):22-23.

Wodecki, M., W.J. Lamont, and M.D. Orzolek. 2001. Center for Plasticulture. 3 Mar. 2002. <http://plasticulture.cas.psu.edu>. 